\title{
Differential returns from globalization to women smallholder coffee and food producers in rural Uganda
}

\author{
*Kanyamurwa $\mathrm{JM}^{1}$, Wamala $\mathrm{S}^{2}$, Baryamutuma $\mathrm{R}^{3}$, Kabwama $\mathrm{E}^{4}$, Loewenson $\mathrm{R}^{5}$
}

1. Kyambogo University, P.O. Box 1, Kyambogo, Uganda

2. Swedish National Institute of Public Health and Karolinska Institute, 83140 Östersund Sweden.

3. Makerere College of Health Services, School of Public Health-Monitoring and Evaluation Technical

Assistance Project (META) P.O. Box 7072, Kampala, Uganda

4. JJ International Research and Training Institute, P.O. Box 36488, Kampala, Uganda

5. Training and Research Support Centre (TARSC) Tanzania, P.O. Box 93, Bagamoyo, Tanzania.

\begin{abstract}
Background: Globalization-related measures to liberalize trade and stimulate export production were applied in Uganda in the late 1980s, including in the coffee production sector, to revitalize agricultural production, increase incomes to farmers and improve rural food security.

Objective: To explore the different effects of such measures on the health and dietary outcomes of female coffee and food small holder farmers in Uganda.

Methods: We gathered evidence through a cross-sectional comparative interview survey of 190 female coffee producers and 191 female food producers in Ntungamo district. The study mostly employed quantitative methods of data collection, targeting the sampled households. We also utilized qualitative data; collected three months after the household survey data had been collected and their analysis had been accomplished. Using qualitative interviews based on an unstructured interview guide, extra qualitative information was collected from key informants at national, district and community levels. This was among other underlying principles to avoid relying on snapshot information earlier collected at household level in order to draw valid and compelling conclusions from the study. We used indicators of production, income, access to food and dietary patterns, women's health and health care. Of the two groups selected from the same area, female coffee producers represented a higher level of integration into liberalised export markets.

Results: Document review suggests that, although Uganda's economy grew in the period, the household economic and social gains after the liberalization measures may have been less than expected. In the survey carried out, both food and coffee producers were similarly poor, involved in small-scale production, and of a similar age and education level. Coffee producers had greater land and livestock ownership, greater access to inputs and higher levels of income and used a wider variety of markets than food producers, but they had to work longer hours to obtain these economic returns, and spent more cash on health care and food from commercial sources. Their health outcomes were similar to those of the food producers, but with poorer dietary outcomes and greater food stress.

Conclusions: The small-scale women farmers who are producing food cannot rely on the economic infrastructure to give them support for meaningful levels of production. However, despite having higher incomes than their food producing counterparts, the evidence showed that women who are producing coffee in Uganda as an export commodity cannot rely on the income from their crops to guarantee their health and nutritional wellbeing, and that the income advantage gained in coffee-producing households has not translated into consistently better health or food security outcomes. Both groups have limited levels of autonomy and control to address these problems.
\end{abstract}

Key words: Globalization, women's health, gender, smallholder farmers, Uganda, nutrition, food security, coffee producers, food producers

African Health Sciences 2013; 13(3): 829 - 841 http://dx.doi.org/10.4314/ahs.v13i3.44

\section{Introduction}

Globalization refers to a process of greater

\section{*Corresponding author:}

John Mary Kanyamurwa

Department of History \& Political Science

Kyambogo University

P.O. Box 1 Kyambogo

Kampala, Uganda

Email: jmkanyamurwa@.kyu.ac.ug

African Health Sciences Vol 13 Issue 3 September 2013 integration within the world economy through the movement of goods and services, capital, technology, labour and information, with increasing influence on national policies ${ }^{1,2,3}$.

In Uganda, economic measures deregulating capital and labour markets and liberalization policies reducing trade and tariff barriers have been motivated by multilateral and global finance and trade 
institutions. These policies have been associated with costs and benefits that accrue differently to different social groups within African countries ${ }^{12}$, , including costs and benefits in terms of social inequalities in economic and health outcomes for smallholder farmers and their households.

After 1987, the Uganda government introduced a series of globalization measures ${ }^{3}$, based on the assumption that the country's agricultural sector had stagnated in the 1980s due to state maintenance of overvalued exchange rates, a monopoly of trade in agricultural products and high levels of inflation ${ }^{4}$. These measures included devaluation of the local currency, restoration of real interest rates through tight control of inflation, adjustment of monetary and fiscal policy ${ }^{5}{ }^{6}$ liberalization of export and import procedures, and the introduction of a foreign exchange auction for importers. In relation to coffee and food farming in Uganda, measures to stimulate export-oriented production have also included an increase in real interest rates to encourage saving among rural farmers, the abolition of export taxes on coffee and the removal of monopoly status from the Coffee and Produce Marketing Boards, which used to be the state's trading boards for coffee and food commodities $^{7}$, . These measures were expected to revitalize agricultural production, increase the income of farmers and improve rural food security'. With improved access to technology, information and know how, such measures were expected to raise household and national resources for human development.

Unfortunately, evidence from the literature suggests that these outcomes may not all have been achieved, especially for rural women ${ }^{1011},{ }^{12}$ Despite some improvements in commodity prices and reports of a decline in aggregate levels of poverty ${ }^{13}$, production levels after the government's liberalization and market reforms remained more or less stagnant, only rising after $1997^{14}$. There were also reports of limited gains in access to agricultural inputs, highly differentiated access to production inputs for different farming groups, high costs of labour inputs and uneven commodity prices ${ }^{15}, 16,17,18$. Female-headed households, in particular, had to deal with these constraints ${ }^{19},{ }^{20}$. In fact, Uganda's coffee market faced a severe decline soon after 1992 and farmers failed to plant new coffee areas until the late 1990s.
Low-income rural women appear to have gained limited benefits from the reforms. Poor, rural women face landlessness, poor access to resources and low asset holdings. They are dependent on work available on other people's farms, with long working hours ${ }^{123}$, . In the 1990 s, they were reported to face food insecurity and poor nutrition ${ }^{456}$, and limited access to education, health care and sanitation. The poorest households were more likely to be femaleheaded households ${ }^{7}$.

Women's health outcomes are a useful means of assessing the social impact of Uganda's economic reforms ${ }^{9}$. Despite an annual gross domestic product (GDP) growth rate of $7 \%$ during 1987-2004, women's health outcomes remained static or worsened ${ }^{10,11}$. Maternal mortality rates (MMR) remained static during the same period, while the availability of emergency obstetric services varied from $4 \%$ to $42 \%$ across districts ${ }^{12}$. Rural-urban differentials did not close and, by 2006, women in rural areas were more than twice as likely as urban women to be underweight $(14 \% \text { versus } 6 \%)^{13}$. A comparison of data for the 2000-2001 and 2006 demographic and health surveys in Uganda revealed that the prevalence of total anaemia grew from 37 to $41 \%$. Improved economic indicators did not translate into improved government funding of the health sector, and public assessments in the early 2000s reported high levels of public dissatisfaction with health care services ${ }^{14}$.

It appears that low-income female farmers appear were unable to access the benefits from these new trade and economic measures, as currency devaluations, privatization and rising prices for private services made basic needs unaffordable to more poor women. Diminished opportunities for paid employment and lengthened hours of work may have further limited the amount of time these women have to attend to their own economic and welfare demands ${ }^{15},{ }_{16}$. Financial and trade liberalization measures also accelerated migration to urban areas ${ }^{17}$, where food and services are more costly, and a combination of a high cost of living and rising unemployment was reported to increase the risk of unsafe sexual practices ${ }^{18}{ }^{19}$. Market reforms brought about user fees and the commercialization of social services, first informally and then as official government policy in 1994, so that even where smallholder rural producers received bigger returns due to price increases, they also paid more for services, such as health care. These changes have been 
associated with a reported rise in socio-economic inequality in Uganda, including lowered access to health services ${ }^{20}$.

The government abolished user fees in early 2001 in the face of increasing evidence that globalization-related measures may not have improved the lives of low-income rural women farmers, as well as data reflecting falling access to and use of health care in the poorest groups and the less-than-anticipated income from commercialization measures, such as cost sharing ${ }^{21}$. Enough evidence exists to cast doubt on the claims that globalizationrelated economic and trade measures have had positive development outcomes in Uganda, but existing literature does not provide adequate evidence to draw clear connections between these measures and the nutrition, dietary and health outcomes of women farmers. Although it is difficult to track the pathways between globalization-related measures and social outcomes, given the complexity and multifactorial nature of these pathways, more research is urgently needed to analyse this issue better.

To address the research gap, which is characterized by mixed reports of the positive and negative effects of globalization measures on women's health and nutrition, as well as inadequate gender disaggregated data in global databases, this case study was implemented as one of three East African case studies on globalization and women's health in subSaharan Africa, in a programme supported by the Swedish Agency for Research Cooperation with Developing Countries (SAREC) and coordinated by the Karolinska Institute and the Training and Research Support Centre (TARSC). The three local-level case studies undertaken in Kenya, Tanzania and Uganda aimed to explore further how women's health and nutrition and their roles as producers, workers and caregivers have been influenced by measures associated with globalization.

By 2009, the globalization measures we noted earlier had already been in place for two decades in Uganda. During that period, trade and export liberalization had primarily been directed at export-oriented coffee producers and less so at farmers producing food for domestic markets. As these two groups have different degrees of integration in global markets, we

African Health Sciences Vol 13 Issue 3 September 2013 examined the nature of this integration through production data, and the returns on integration through evidence on food security, nutrition and health.

\section{Methods}

We carried out a cross-sectional interview survey comparing female-headed households mainly occupied with coffee production and female-headed households mainly occupied with food production, with the two groups defined by the percentage of land allocated to growing coffee or food. After completing a literature review, we conducted an interviewer-administered household survey during the months of September and October 2008, using a structured questionnaire.

The survey was implemented in Ntungamo, a rural district in south-western Uganda. Ntungamo district covers an area of 2,055.5 $\mathrm{km}^{2}$ and consists of the three counties of Ruhaama, Rushenyi and Kajara, which are further divided into 16 sub-counties, 82 parishes and 851 villages. The district has an estimated total population of 398,324 people, of which $42 \%$ are male and $58 \%$ female. It is primarily rural $(99.1 \% \text { of households) })^{45}$, with $5 \%$ of the population shares under the age of one, $19 \%$ under the age of five and $23 \%$ of women of child-bearing age (15-49 years). The average household size is seven people. We chose this district as it has a higher share of female-headed households, produces a high share coffee from smallholder farms and also has smallholder food producers. The area has a number of coffee hulleries and most of the coffee produced in the area is exported by foreign-owned private companies, which control approximately $80 \%$ of the crop. Although there are over 15 indigenous coffee firms that still operate in the market, their influence remains minimal, due to limited capital, indebtedness and poor management. The smallholder food farmers in this district grow bananas (under attack from banana weevils at the time of the survey), sweet potatoes, millet, cassava, beans, soybeans and groundnuts.

The study populations were female-headed smallholder households engaged in coffee crop production and female-headed smallholder 
households engaged in food crop production. Within the study area, Ntungamo district, and in Kajara County, the coffee producers were selected from Kyakakama, Ibaare I, Ibaare II, Rukoni Central, Nyakatunguru, Nyarwiina, Kibaruko, Rweibare, and Rubingo parishes. The food producers were selected from Kibatsi, Murambi, Kihumuro, Rucence, Kamoshe, Nyamugoye, Kishibire, Rutooma and Runyinya parishes. Coffee producers were distinguished from food producers by the percentage of land allocated to growing coffee or food. Those with over a quarter of their land committed to growing coffee and under a quarter of their land allocated to growing food were classified as coffee producers. We applied the reverse classification to those regarded as food producers. A large proportion of coffee producers $(71.1 \%)$ allocated over half of their land to coffee growing, and $80 \%$ of food producers did likewise for food cultivation.

We used cluster sampling to select villages within Kibatsi sub-country, and randomly selected households for interviews from village lists compiled by researchers. We interviewed the female head of household. To determine the sample size for the household survey, from a population of 5,000 and with unrestricted, independent random variables, we used Bernard's sample determination table to draw a sample of 384. Hence, we selected 192 coffeeand 192 food-growing female-headed households.

The study largely employed quantitative methods of data collection with the household as the basic unit of analysis. In addition, 23 qualitative interviews based on an unstructured interview guide were collected after the household survey mainly to produce in-depth and comprehensive information on the consequences of globalization on female headed smallholder coffee and food producing households. Moreover, this qualitative element of the study was added three months after the household survey to generate detailed data to further illuminate the context of female headed households and the key relationships with the globalization phenomenon. Emphasis in this analysis was put on the impact of globalization on agriculture, women occupational roles, food expenditure and nature of markets, households' and women's expenditure on health as well as other variables considered as identified earlier. Therefore, together with key informants from key interviewees at national, district and community levels, the study collected further data to complement the household level information that goes well beyond the snapshot information collected at household level.

While these women may have been in marriage partnerships, their male partners were not resident on their farms, so the women were the de facto heads of their households. Three households dropped out of the study for personal reasons (two coffee producers and one food producer) and we consider this rate of loss to the sample too low to raise any systematic bias.

We identified variables ranging from individual and household levels to global levels in the pathways between globalization, women's role as coffee and food farmers and household health and nutrition outcomes, as outlined in table 1 . We collected data according to the variables for community, household and individual levels.

We cleaned and analysed the data using SPSS and conducted a content analysis of the qualitative data. The protocol and tools were peer reviewed and the resulting protocol was cleared by the Uganda National Council for Science and Technology (UNCST), the ethics institution in Uganda. Permission was also granted by the Resident District Commissioner (RDC) in Ntungamo District, the local administration officials in the sampled areas and the respondents.

\section{Results}

\section{Socio-demographic characteristics}

The age of the women coffee and food producers was mainly between 25 and 39 years $(78.4 \%$ and $86.8 \%$ respectively), implying that these women have to juggle both productive and reproductive needs and roles. Almost a third (32\%) of both coffee and food producers had attained primary education, and the two groups had the same literacy levels, with only a small fraction having had no education at all (6\% of coffee producers and $6.3 \%$ of food producers). Therefore it appears that the two groups did not differ significantly in age or educational status, both of which are major determinants of health outcomes. Most smallholder coffee producers $(72.1 \%)$ and rural food producers $(62.8 \%)$ earned their income from small-scale farming, so that there was also no significant difference in the scale of production. Despite working in different areas of production (coffee and food), both groups operated largely within the informal economy in terms of capital, production and marketing $(88.9 \%$ of coffee producers and $80.6 \%$ of food producers). 
Table 1: Variables used for this study's data collection and analysis

\begin{tabular}{|c|c|}
\hline $\begin{array}{l}\text { Levels of } \\
\text { influence }\end{array}$ & Variables \\
\hline Global level & $\begin{array}{l}\text { From the literature review: Trade and tariff reform; liberalization of foreign exchange } \\
\text { markets; the role of state and marketing board in production and marketing; subsidies; } \\
\text { import controls; export incentives; trade agreements. }\end{array}$ \\
\hline National level & $\begin{array}{l}\text { From the literature review and key informant interviews: Producer incentives (crops } \\
\text { and products) and their application; land ownership and inheritance policies; access to } \\
\text { inputs, credit, support services and extension services; input and crop subsidies; water; } \\
\text { transport and communication infrastructure, including access; food markets and pricing } \\
\text { policies. }\end{array}$ \\
\hline $\begin{array}{l}\text { Community } \\
\text { level }\end{array}$ & $\begin{array}{l}\text { From the household and key informant interviews: Food availability in local markets; } \\
\text { food sources; amounts and varieties of food consumed; factors affecting dietary choices } \\
\text { and patterns (including seasonal differences); access to state subsidies; investments in } \\
\text { food markets and production. }\end{array}$ \\
\hline $\begin{array}{l}\text { Household } \\
\text { and } \\
\text { individual } \\
\text { level }\end{array}$ & $\begin{array}{l}\text { From the household interview: Women's workloads; trade-offs on occupational roles; } \\
\text { food sources; amounts and varieties purchased, stored, grown and consumed; income } \\
\text { spent on food; signs of stress in food security (eg: sale of assets to procure food); dietary } \\
\text { choices; determinants and patterns focusing on children under the age of five; females } \\
\text { aged 15-49; duration of breastfeeding last child; seasonal changes in household and } \\
\text { individual variables. }\end{array}$ \\
\hline
\end{tabular}

All food producers and $84 \%$ of coffee producers had children, and most of the respondents had very young children, with food producers having significantly more children than coffee producers ( figure 1). Coffee producers $(65 \%)$ generally had larger households (most with four or five members) compared with food producers (most with only one to three members) $\left(\mathrm{Chi}^{2}=138.23, \mathrm{p}<0.0001\right)$, and more members of the extended family were found in coffee producer households. Food-producing mothers were younger at the birth of their last child than coffee producers, although there was no significant difference between the mean ages of the mothers (30.3 years for coffee producers and 30.1 years for food producers).

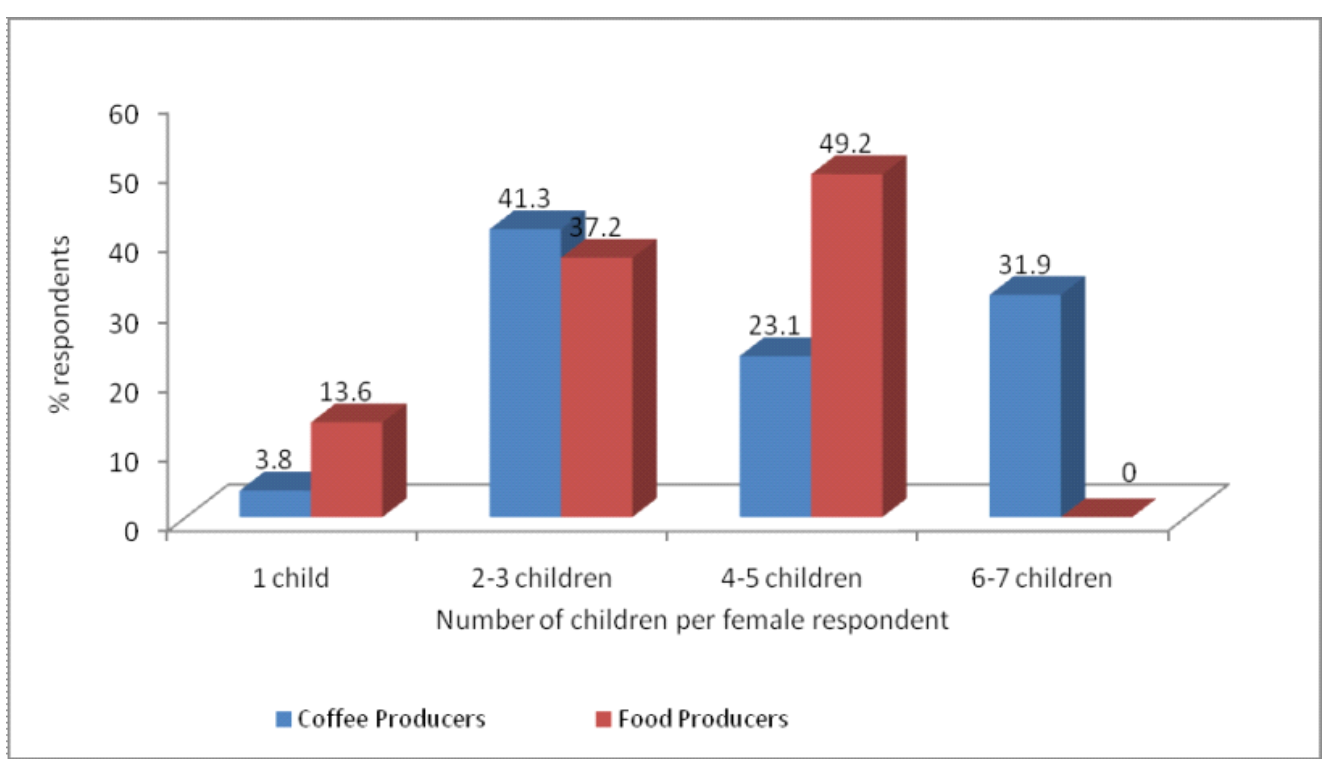

Figure 1: Frequency of childbirth in coffee and food producing households $(\mathrm{N}$ food producers $=191 ; \mathrm{N}$ coffee producers $=160)$ 
Apart from differences in the number of children, the two groups of farmers were similar in the key areas of demographic and economic status, providing a reasonable basis for exploring women's occupational roles, nutrition and the health effects of the different choices of production of coffee or food.

\section{Access to and control over production inputs}

There was a significant difference in the type of small livestock held by the two respondent groups $\left(\mathrm{Chi}^{2}\right.$ $=59.185, \mathrm{p}<0.0001)$, as well as large livestock $\left(\mathrm{Chi}^{2}\right.$ $=75.878, \mathrm{p}<0.0001)$. Coffee producers held significantly more small and large livestock than food producers (see table 3). Most coffee producers $(72.6 \%)$ had goats, whereas food producers largely had sheep (48.2\%) and, with regard to large livestock, all food producers had local cattle breeds, while $66.8 \%$ of coffee producers had local cattle breeds and $16.8 \%$ had exotic cattle breeds (from outside the area), a sign of greater access to more costly livestock.

All food producers cultivated land owned by their spouses or other family members. Of the coffee producers, only $10.5 \%$ owned their land, while $31.1 \%$ farmed land that was owned by family members and $8.9 \%$ rented. The two groups were significantly different in terms of land ownership $\left(\mathrm{Chi}^{2}=129.012, \mathrm{p}<0.0001\right)$, although neither had any meaningful level of control of the land they cultivated.

There was also a significant difference in access to agricultural inputs across respondent categories. Generally, coffee producers were in a significantly better position than food producers to access seedlings and adequate credit, and in their ability to buy agricultural inputs $\left(\mathrm{Chi}^{2}=37.136\right.$, $\mathrm{p}<0.0001$ ), although food producers had greater access to fertilizer (28\% versus $15 \%$ - see table 4 ). While $33.5 \%$ of food producers could buy inputs for themselves in the past season, only $17.6 \%$ of coffee producers were able to procure inputs, suggesting that both groups experienced problems in this regard, only more so for food producers.

For the 2007 agricultural season, there was a significant difference in the number of hours spent on household activities $\left(\mathrm{Chi}^{2}=31.228, \mathrm{p}<0.0001\right)$ and on farming activities $\left(\mathrm{Chi}^{2}=49.902, \mathrm{p}<0.0001\right)$, with coffee producers spending more time than food producers on both household and farming activities. Both groups spent one to three hours on household activities during peak farming time. However, 90.6\% of food producers spent four to six hours on farming activities during peak time whereas, among the coffee producers, $75 \%$ spent four to six hours on farming and $20 \%$ spent seven hours or more. There were also significant differences in the number of hours spent on activities outside the peak season, in terms of household activities $\left(\mathrm{Chi}^{2}=44.93\right.$, $\mathrm{p}<0.0001)$, farming activities $\left(\mathrm{Chi}^{2}=124.13\right.$, $\mathrm{p}<0.0001)$ and food preparation $\left(\mathrm{Chi}^{2}=31.23\right.$, $\mathrm{p}<0.0001)$. During the off season, coffee producers spent significantly less time than food producers on household activities, and food producers spent significantly more time on farm activities. Generally, coffee producers spent more time working on all activities combined, particularly during peak season.

\section{Household incomes}

While personal monthly incomes were low for both groups, they were significantly lower for food producers $(\mathrm{p}<0.0001)$. Most food producers $(61 \%)$ earned 5,000-10,000 Uganda shillings monthly $\left(\mathrm{Chi}^{2}\right.$ $=72.57, \mathrm{p}<0.0001$; see figure 2 ). Household incomes were a little higher than personal incomes, as other members of households were earning incomes, especially in coffee-producing households. While food producers were poorer than coffee-producing households, all the female-headed households were poor, and both groups relied on remittances from other household members.

\section{Decision making}

Women coffee producers were found to have significantly more control over spending decisions on food than food producers $(p<0.001$, see table 5). Regarding decisions on health care, women who headed households in food-producing households had more control than those in coffee-producing households, but not significantly so.

\section{Health issues}

When we assessed respondents' health status in relation to self-rated health and illnesses, healthseeking behaviour and reproductive health, we found a significant difference in the general health status between the two groups. More coffee producers $(33.2 \%)$ than food producers $(17.8 \%)$ reported having experienced long-term illness, although only $23 \%$ of food producers reported that they felt well at the time of the survey, compared to $58 \%$ of coffee producers $\left(\mathrm{Chi}^{2}=48.202, \mathrm{p}<0.0001\right)$. 


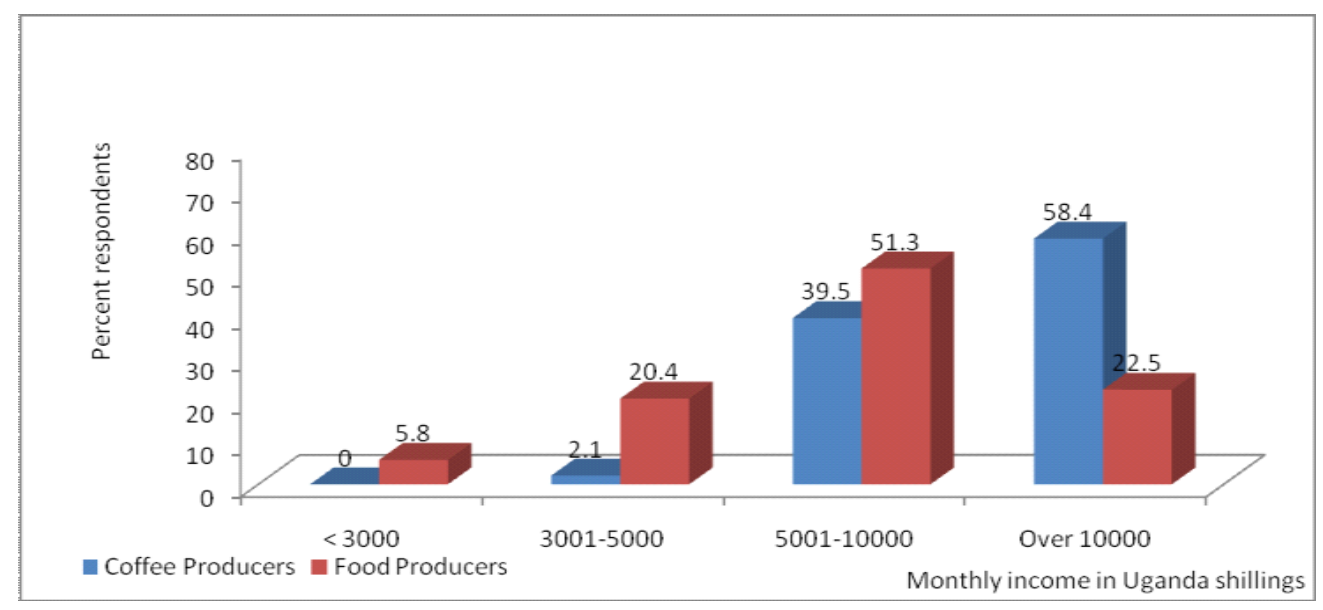

Figure 2: Household monthly incomes for female coffee and food producers (2013 value US\$1=2580 Uganda Shillings)

Of the 95 respondents who sought antenatal services - an important entry point for women's and reproductive health care services - those from coffee-producing households were more likely to be using private health facilities (where costs are higher), while food producers were more likely to use public services. Respondents from foodproducing households more commonly reported using untrained health workers (see table 2).

Over two-thirds of coffee producers (68\%) and food producers $(66 \%)$ reported that they did not seek antenatal services during pregnancy, either because they felt well throughout the pregnancy (20\% and $12 \%$ respectively), did not know whether to use antenatal services (25\% in both groups), or were ignorant of antenatal services (34\% and 40\% respectively). Nevertheless the need for improved antenatal and maternal health care was evident in both groups. Although about half of both coffee- and food-producing households with a prior pregnancy reported no pregnancy complications in their last pregnancy (56\% and 54\% respectively), the rest reported a variety of complications such as threatening abortion ( $10 \%$ of both groups), bleeding (38\% and $35 \%$ for coffee and food producers respectively), raised blood pressure (16\% and $44 \%$ respectively) and oedema (36\% and $12 \%$ respectively).

We found significant differences in the use of services for childbirth between the two groups. While $52 \%$ of the coffee producers were assisted in their delivery by trained health workers, only $11 \%$ of the food producers were assisted by trained health workers, with $89 \%$ being supported by traditional birth attendants $\left(\mathrm{Chi}^{2}=54.15, \mathrm{p}<0.0001\right)$.

Table 2: Antenatal services used by women in food- and coffee-producing households

\begin{tabular}{|c|c|c|c|}
\hline Sources of antenatal services & $\begin{array}{l}\text { Responses } \\
\% \text { coffee producers } \\
{[n=44]}\end{array}$ & $\begin{array}{l}\% \text { food producers } \\
{[\mathrm{n}=51]}\end{array}$ & $\begin{array}{l}\text { Total \% } \\
{[\mathrm{n}=95]}\end{array}$ \\
\hline Public health facility & 20.5 & 27.5 & 24.2 \\
\hline Private health facility & 11.4 & 5.9 & 8.4 \\
\hline $\begin{array}{l}\text { Non-governmental organization/ } \\
\text { Faith-based facility }\end{array}$ & 13.6 & 7.8 & 10.5 \\
\hline Traditional healers & 25.0 & 23.5 & 24.2 \\
\hline $\begin{array}{l}\text { Community health workers trained in } \\
\text { health services }\end{array}$ & 25.0 & 21.6 & 23.2 \\
\hline Untrained health workers & 4.5 & 13.7 & 9.5 \\
\hline Total & {$[100.0]$} & {$[100.0]$} & [100.0] \\
\hline
\end{tabular}


Both groups had similar patterns in the uptake of general health services. Of those reporting any illness in the previous month, 59\% of coffee producers and $55 \%$ of food producers did not use any health services. There was no significant difference in the pattern of health-seeking behaviour or the frequency of medicine purchases between the two groups in the month prior to the survey. The reasons given for not seeking health care for the last illness included disappearance of the pain, long queues at health centres, long distances to health care facilities, lack of money, lack of time and not knowing where to go (see table 3). As shown in the table, food producers more commonly cited cost and distance as barriers to drug purchases. In both groups, $21.2 \%$ of women used traditional healers.

There was a significant difference in the mode of payment between food and coffee producers, with $80 \%$ of coffee producers paying cash and $93 \%$ of food producers paying 'in kind' with farm or other goods $\left(\mathrm{Chi}^{2}=53.64, \mathrm{p}<0.0001\right)$. There was also a significant difference in who paid medical costs, with $41 \%$ of coffee producers reporting that the children's fathers paid the bills, while food producers reported bills being paid by church/social groups (26\%), family members or community organizations $(21 \%$ each) and mothers themselves (19\%) $\left(\mathrm{Chi}^{2}=29.49\right.$, $\mathrm{p}<0.0001$ ). Our earlier finding (see table 5) that women in coffee-producing households have less say than their food-producing counterparts in health care spending decisions may be because their male partners pay the bills more often $(41 \%)$.

\section{Access to markets and food security}

We gathered information on markets used for the sale of produce and purchase of goods to analyze returns from production and sources of food. The respondents differed significantly in where they sold their produce $\left(\mathrm{Chi}^{2}=33.76, \mathrm{p}<0.0001\right)$. Both coffee and food producers sold produce to local village markets ( $75 \%$ and $71 \%$ respectively), but more coffee than food producers also sold produce in neighbouring villages (24\% and $12 \%$ respectively), and more food than coffee producers also sold produce at the nearest trading centre $(17 \%$ and $1 \%$ respectively). Food producers were thus more likely to sell locally, less aware of available markets, and more likely to cite distance to the trading centre as a barrier to market access. Most of the food producers $(88 \%)$ did not own storage facilities for their harvests.

We found that coffee producers were more worried about household food security than food producers, with half reporting concerns on a range of questions around food security, compared to about a third $(36 \%)$ of food producers (see table 4). We also asked respondents about the food that they had eaten at breakfast, lunch and supper the previous day. There was a significant difference in the reported diets of the two groups for all three of the meals, with regular consumption of fruit, legumes, vitamin A-rich vegetables and cereals in less than $20 \%$ of coffee-producing households compared to more than $80 \%$ of food-producing households $(\mathrm{p}<0.001)$.

Table 3: Reasons for food and coffee producers patterns of health care uptake

\begin{tabular}{llll}
\hline $\begin{array}{l}\text { Reasons given for } \\
\text { not seeking health care }\end{array}$ & $\begin{array}{l}\text { \% coffee producers } \\
{[\mathbf{n}=\mathbf{1 1 2}]}\end{array}$ & $\begin{array}{l}\text { \% food producers } \\
{[\mathbf{n}=\mathbf{1 0 5}]}\end{array}$ & $\begin{array}{l}\text { Total \% } \\
{[\mathbf{n}=\mathbf{2 1 7}]}\end{array}$ \\
\hline Pain disappeared & 22.2 & 3.8 & 12.9 \\
There was a long queue & 14.4 & 1.9 & 8.1 \\
Long distance & 24.1 & 13.3 & 18.7 \\
Didn't have the money & 16.3 & 63.8 & 40.2 \\
Didn't have time & 6.7 & 1.9 & 4.3 \\
Didn't know where to go & 16.3 & 15.3 & 15.8 \\
[Total] & {$[100.0]$} & {$[100.0]$} & {$[100.0]$} \\
Reasons given for not & $\%$ coffee producers & $\%$ food producers & Total \% \\
buying medicine & {$[\mathrm{n}=98]$} & {$[\mathrm{n}=113]$} & {$[\mathrm{n}=211]$} \\
I got well & 13.5 & 1.8 & 7.4 \\
Didn't have money & 13.5 & 12.4 & 12.9 \\
Had medicine at home & 18.3 & 16.8 & 17.5 \\
Long distance to drug store & 11.5 & 27.4 & 19.8 \\
Didn't think medicine would help 8.6 & 2.7 & 5.5 \\
Church prayed for me & 13.5 & 17.7 & 15.7 \\
Treated by a traditional doctor & 21.1 & 21.2 & 21.2 \\
Total & {$[\mathbf{1 0 0 . 0 ]}$} & {$[\mathbf{1 0 0 . 0 ]}$} & {$[\mathbf{1 0 0 . 0 ]}$} \\
\hline
\end{tabular}


Table 4: Food security and dietary patterns among food and coffee producers

\begin{tabular}{|c|c|c|c|c|c|c|c|c|c|c|c|c|c|c|}
\hline \multirow[t]{2}{*}{ Survey questions } & \multicolumn{4}{|c|}{$\begin{array}{c}\text { Coffee producers } \\
{[n=190]}\end{array}$} & \multicolumn{4}{|c|}{$\begin{array}{l}\text { Food producers } \\
{[\mathrm{n}=191]}\end{array}$} & \multicolumn{4}{|c|}{$\begin{array}{c}\text { Total } \\
{[n=381]}\end{array}$} & \multirow[t]{2}{*}{$\chi^{2}$} & \multirow[t]{2}{*}{ Pvalue } \\
\hline & Yes & $\%$ & No & $\%$ & $\overline{\text { Yes }}$ & $\%$ & No & $\%$ & $\overline{\text { Yes }}$ & $\%$ & No & $\%$ & & \\
\hline $\begin{array}{l}\text { In the past four weeks, did you } \\
\text { worry that your household } \\
\text { would not have enough food? }\end{array}$ & 93 & 49 & 97 & 51 & 67 & 35 & 124 & 65 & 160 & 42 & 221 & 58 & 7.52 & $<0.005$ \\
\hline $\begin{array}{l}\text { In the past four weeks, did any } \\
\text { household member eat fewer } \\
\text { meals, as there was not enough } \\
\text { food? }\end{array}$ & 95 & 50 & 95 & 50 & 70 & 37 & 121 & 63 & 165 & 43 & 216 & 57 & 6.02 & $<0.01$ \\
\hline $\begin{array}{l}\text { In the past four weeks, did you } \\
\text { have no food to eat in your } \\
\text { house, due to lack of } \\
\text { resources? }\end{array}$ & 95 & 50 & 95 & 50 & 73 & 38 & 118 & 62 & 168 & 44 & 213 & 56 & 5.36 & $<0.05$ \\
\hline $\begin{array}{l}\text { In the past four weeks, did any } \\
\text { household member go to sleep } \\
\text { hungry as there was not } \\
\text { enough food? }\end{array}$ & 95 & 50 & 95 & 50 & 67 & 35 & 124 & 65 & 162 & 43 & 219 & 58 & 8.68 & $<0.005$ \\
\hline Average & 95 & 50 & 95 & 50 & 69 & 36 & 122 & 64 & 164 & 40 & 217 & 60 & 7.48 & $<0.01$ \\
\hline
\end{tabular}

At the time of our study, the price of $10 \mathrm{~kg}$ of cereal from the local market was between 3,000 and 5,000 Uganda shillings (nominally US $\$ 1.5-2.6$ ), while $250 \mathrm{ml}$ of oil at local market rates cost 1,5002,000 shillings ( $\$ 0.75-1)$. The price of $10 \mathrm{~kg}$ cereal comprised between 25 and $50 \%$ of the median income of the households reported earlier, which represents a high financial burden. Coffee producers spent significantly more on food every month than food producers $\left(\mathrm{Chi}^{2}=138.31, \mathrm{p}<0.0001\right)$. Among the coffee producers, $84 \%$ spent $10,000-20,000$ shillings (\$5-10) in the course of a month, compared to food producers, of whom $59 \%$ spent less than 10,000 shillings $(<\$ 5)$ on food per month. Although food producers had better dietary patterns and less stress over food, they also spent less on food than coffee producers, and were less reliant on highpriced commercial markets for food. Coffeeproducing households were more likely to have sold assets to meet food costs $(11 \%)$ than food-producing households $(5 \%-\mathrm{p}<0.05)$.

\section{Discussion}

The results of the field survey indicate that both food and coffee producers were similar in many respects. They were all poor, involved in small-scale production, largely in the informal economy for inputs and capital needs, and of a similar age and education level. Coffee-producing households had more children, and informants observed that, if the children found paid work, they could augment the household income, but noted that supporting children also raised household costs.

Coffee producers appeared to be wealthier in terms of greater land ownership, greater ownership of livestock, greater incomes and greater access to inputs. In these respects, coffee producers, who are more affected by Uganda's globalizationrelated, export-oriented market reforms, appear to have a better income than food producers. As this was a cross-sectional survey, we could not accurately determine whether their greater level of landholdings and assets were a result of their choice to grow coffee or a differentiating feature that enabled them to grow coffee. Nevertheless, their income returns were more favourable than those for food producers. Coffee producers were also found to use a wider variety of markets than food producers, with the latter more restricted to sales in their own local communities. This too may restrict income opportunities for this group, given the poverty levels in the local community.

Nevertheless, we found that the benefits enjoyed by coffee growers came at a cost. Both 
groups spent long hours on farming and household activities (up to ten hours a day), but coffee producers worked longer to obtain their higher economic returns. They were also more likely to use private services for health and more frequently paid cash for health care. They spent more of their income on food but, despite this, they were more worried about their household food security and had poorer reported diets. Their reliance on commercial markets for food appears to have not given them the same quality of diet that those who grew food obtained.

Coffee producers had significantly higher levels of skilled assistance at birth, an important area of health gain. On other health indicators, however, there were no significant differences between the two groups with respect to reported pregnancy complications, antenatal care use or health-seeking behaviour patterns. While food producers reported lower levels of immediate wellbeing at the time of the survey, coffee producers reported higher levels of chronic illness.

While the improved incomes of coffee producers gave them greater market choice and purchasing power, this did not appear to bring them better health outcomes and, in relation to food security, they appeared to be more reliant on buying food, and have poor dietary patterns and greater stress over food security. The significantly higher level of sale of assets for food found in coffeeproducing households further indicates this higher level of stress.

We were not able to measure child nutritional status and this would be an important further assessment to do in these households on the basis of the findings from our survey. Even without this data, the evidence we gathered suggests that the income advantage gained in coffee-producing households has not translated into consistently better health or food security outcomes, using the parameters studied.

There were also differences in autonomy over incomes - production assets were largely jointly controlled or owned by other parties in the family in both groups. While coffee-producing women were more likely to purchase food and health care, they were also reported to be more reliant on financial decisions of their male spouses than food producers, and the costs were often paid by the men. For the food producers, the women were reported to have greater control over decisions on spending, but they were also found to be more dependent on social groups in the community. This may be why we found a lower use of formal services and greater use of community-level traditional care in food producers. Food producers also had greater household control over the food they consumed because they produced some of it themselves, even though they were also reported to have limited facilities for food storage. Food producers thus appeared to have greater control over their resources - even though these were more limited - and were more connected with community associational mechanisms for solving problems. Women coffee producers appeared to be more reliant on family income and cash and had less control over these sources of income.

\section{Conclusion}

In the preceding discussion this paper has articulated the extent to which globalization measures have impacted on two different categories of smallholder female headed households. Clearly, for these women agricultural producers, the effects of globalization seem to have led to loss of socio-economic security and control over resources for food production as well as leading to inequality in health access. This view is supported by data that seems to indicate that the coffee producers' expenditure on health was greater than other socio-economic monetary commitments. This evidence is linked to the information we gathered from literature review that suggests heavy expenditure on both food and health needs of the female headed household in rural Uganda mainly as a result of healthcare commercialization.

In short, rather than extend the horizons for access to health for women, globalization has reduced the opportunities for improving women's health in rural areas with more women continuing to lack access to professional health services, unchanged employment patterns, workloads and spending more time on unpaid activities. Nevertheless, the latter phenomena control women's mobility between their households and the farm, inhibiting their access to health services since in most cases these services tend not to be available in the neighbourhood, or even within easy reach in rural areas. This analysis raises a strong need for regulating the agricultural sector, particularly the women's relationship with the market to help them to access more fair markets since it is the basis for socioeconomic determinants of health for the smallholder agricultural producers in rural areas. 
Results from our field study further indicate that the cash incomes from coffee production have given coffee-producing households greater resources than food producers to pay for household needs, including for food and health care, although at the cost of longer working hours. Nonetheless, they experience higher levels of food stress, as well as poorer diets and sell more assets to buy food, which means that their gains in income still cannot meet their household needs. They also tend to rely more on private health services, which cost more, and were not found to have better health than food-producing households.

Our study confirms previous research indicating that the commercialization of health services and food sources may be associated with falling local food self-sufficiency and poorer health and nutritional outcomes. While the market may increase the range of commodities commercially available, it does not necessarily secure access to those commodities. Those who are increasingly integrated into liberalized markets, such as the coffee producers, face challenges of price volatility and rising prices of commodities and services outside their control. They may in fact divert to production the resources needed for household health and wellbeing, as in the case of women coffee growers working longer hours during peak season.

It appear that, in Uganda, small-scale women farmers who are producing an export commodity like coffee cannot rely on the income they get from their crops to guarantee their personal or family health and nutritional wellbeing. Our results also indicate that small-scale women farmers producing food cannot rely on the economic infrastructure to give them support for meaningful levels of production. Both bear a significant burden, with limited levels of autonomy and control to address it.

Neither small-scale coffee or food farmers appear to be the real beneficiaries of the economic reforms introduced by globalization. Both groups have limited land ownership and high workloads, and spend significant time on farming and domestic activities, with limited returns. They also face limited availability of health services and of food.

The study suggests that relying on integration into global, export-oriented markets is unlikely to improve food security or health in small-scale farmers in Uganda. It would appear from the evidence that additional economic measures are needed to improve these indicators. A review of the literature suggests that these include measures such as: improving land ownership in women and improving women smallholder farmers' access to incentives for production, production inputs and information ${ }^{4}$. Government should take measures to stimulate domestic markets, particularly for healthy food crops, and support local processing, particularly where value-added steps in production can be done in Uganda.

Although commercializing health services may appear to offer better choices for end-users, we found that it may also erode household incomes and negatively affect health-seeking behaviours, even of those who may appear to be able to afford it. We call for enhanced access to comprehensive primary health care services and the abolition of user fees, backed by adequate public spending on these services.

\section{Acknowledgements}

This study is part of the international research project, 'Globalization and women's health in sub-Saharan Africa', and is financed by the Sida/Sarec. We are indebted to the members and advisors of the research project.

\section{References}

1. De Vogli R, Birbeck GL. Potential impact of adjustment policies on vulnerability of women and children to HIV/AIDS in Sub-Saharan Africa. J of Health Pop and Nutr 2005; 23:105120.

2. Collins T. Globalization, global health and access to health care. Int J Health Plann Mgmt 2003;18:97-104.

3. Loewenson R, Nolen A, Wamala S. Globalization and women's health in Saharan Africa: would paying attention to women's occupational roles improve nutritional outcomes? Scand J Public Health 2010; 38:6-17.

4. Wamala S, Breman A, Richardson M, Loewenson R. Can the Millennium Development Goals database be used to measure the effects of globalization on women's health in sub-Saharan Africa? A critical analysis. Scand J Public Health 2010; 38:18-28.

5. Katorobo J. Reforming the export marketing system: monopoly vs. competition in export marketing. In Uganda: Landmarks in Rebuilding a Nation. Edited by Langseth P, Katorobo J, Brett 
E, Munene J. Kampala: Fountain Publishers; 1995: 68-89.

6. Nyamugasira W. Structural adjustment, land reform, and disenfranchisement in Uganda. Development in Practice 1996; 6(4):pp-pp.347-351.

7. Bazaara N. Structural Adjustment Participatory Review Initiative (SAPRI) Uganda: impact of liberalization on agriculture and food security in Uganda. Report. Kampala: Centre for Basic Research; 2001.

8. Baffoe JK. Structural adjustment and agriculture in Uganda. Sectoral Activities Programme Working Paper 149. Geneva: International Labour Office; 2000.

9. Tumusiime-Mutebile E: Selected issues in stabilization and adjustment policy in Uganda. Discussion Paper 3. Kampala: Ministry of Finance Planning and Economic Development; 1990.

10. Brett EA. Adjustment policy and institutional reform in Uganda. In Uganda: Landmarks in Rebuilding a Nation. Edited by Langseth P, Katorobo J, Brett E, Munene J. Kampala: Fountain Publishers; 1995:26-34.

11. Balihuta AM, Kunal S. Macroeconomic policies and rural livelihood diversification: a Ugandan case study. LADDER Working Paper 3. United Kingdom: LADDER; 2001.

12. Appleton S, Emwanu T, Kagugube J, Muwonge J. Changes in poverty in Uganda, 1992-1997. Oxford: Centre for the Study of African Economies, University of Oxford; 1999.

13. Appleton S: Women-headed households and poverty: an empirical deconstruction for Uganda. World Derpmt 1996; 24(12):1811-1827.

14. Bigsten A. Globalization and income inequality in Uganda. For.Organization for Economic Co-operation and Development (OECD) project on Globalisation and Income Inequality. OECD, Paris, 2000.

15. Ministry of Finance, Planning and Economic Planning: Poverty Eradication Action Plan 2004/ 5-2007/8. Kampala: Government of Uganda; 2004.

16. Ministry of Agriculture, Animal Industry and Fisheries, Ministry of Finance, Planning and Economic Planning. Plan for Modernization of Agriculture, Eradicating Poverty in Uganda. Government Strategy and Operational Framework. Kampala: Government of Uganda; 2000.

17. Kanyamurwa JM, Ampek GT: Gender differentiation in community responses to AIDS in rural Uganda. AIDS Care 2007, 19 (Suppl 1):S64-S72.
18. Tumusiime-Mutebile E. Economic reforms and their impact in Uganda. Working Paper W00:13, Iceland: Institute of Economic Studies; http:/ /www.ioes.hi.is/publications/wp/w0013.pdf 2000.

19. Uganda Coffee Development Authority: Key indicators in the coffee sub-sector since liberalization. Kampala: Government of Uganda; 2001.

20. Wamala S, Kawachi I. Globalization and women's health. In Globalization and Health. Edited by Kawachi I, Wamala S. Oxford: Oxford University Press; 2007.

21. Uganda Bureau of Statistics: Housing and Population Census Report, 1991. Kampala: Government of Uganda; 1992.

22. Hilary J. The Wrong Model: GATS, Trade Liberalization and Children's Right to Health. London: Save the Children Fund; 2001.

23. Roth M, Jeffrey A, Cochrane J, KisambaMugerwa W. Tenure Security, Credit Use, and Farm Investment in the Rujumbura Pilot Land Registration Scheme, Rukungiri District, Uganda. Madison, Wisc.: Univ. Land Tenure Center, 1993.

24. Elson D. The impacts of structural adjustment on women: concepts and issues. In The IMF, World Bank and the African Debt. Volume 2. Edited by Onimode B. London Zed Books; 1989.

25. Mwaka, VM. Agricultural production and women's time budgets in Uganda. In Different Places, Different Voices: Gender and Development in Africa, Asia and Latin America. Edited by Momsen JH, Kinnaird V. New York: Routledge; 1993:46-51.

26. Uganda Food and Nutrition Council. National Food and Nutrition Strategy: Background Information, Final draft. Uganda: Uganda Food and Nutrition Council; 2005.

27. Jitta J, Migadde M, Mudusu J. Determinants of Malnutrition in Under-five Children in Uganda: An In-depth Secondary Analysis of the UDHS 1988/ 89 Data. Kampala: Ministry of Health, Uganda and Child Health and Development, Makerere University; 1992.

28. Uganda Bureau of Statistics, United States Agency for International Development, ORC Macro. Uganda, 2000-2001, Nutrition of Young Children and Mothers. Calverton, United States: ORC Macro; 2001.

29. Food and Agriculture Organization. The State of Food Insecurity in the World 2003. Rome: Food and Agriculture Organization; 2003.

African Health Sciences Vol 13 Issue 3 September 2013 
30. International Food Policy Research Institute: Assuring Food and Nutrition Security in Africa by 2020, Prioritizing action, Strengthening Actors and Facilitating Partnerships. April 1-3, 2004, Kampala, Uganda; Kampala: International Food Policy Research Institute; 2004. http:// conferences.ifpri.org/2020africaconference/ program/day2summaries/sekitoleko.pdf.

31. Ministry of Finance, Planning and Economic Development: National Food Strategy: A Response to the Challenge of Poverty. Kampala: Government of Uganda; 1996.

32. Government of Uganda. Policy statement on abolition of user-charges and introduction of a dual system. Uganda Health Bulletin 2001; $7(2): 7-16$

33. Ministry of Agriculture, Monitoring and Evaluation Unit: Agricultural Development Project: Evaluation Report. Uganda: Government of Uganda; 1991.

34. Nsamba-Gayiiya E. Implementing Land Tenure Reform in Uganda. London: IIED Drylands Programme; 1999.

35. Chen S, Ravallion M. How have the poorest fared since the early 1980s? World Bank Research Observer 2004; 19(2): 141-169.

36. Brownbridge M. Financing the millennium development goals: is more public spending the best way to meet poverty reduction targets? Health Policy Dev 2004; 2:40-47.

37. Mwaka, VM: Agricultural production and women's time budgets in Uganda. In Different Places, Different Voices: Gender and Development in Africa, Asia and Latin America. Edited by
Momsen JH, Kinnaird V. London: Routledge; 1993:46-51.

38. Diderichsen F, Evans T, Whitehead M. The social basis of disparities in health. In Challenging Inequities in Health: From Ethics to Action. Edited by Whitehead M, Evans T, Diderichsen F, Bhuiya A, Wirth M. New York: Oxford University Press; 2001:12-23.

39. Fontana M. The gender effects of trade liberalization in developing countries: a review of literature. Paper prepared for 2008 UNCTAD International Seminar. Brighton: University of Sussex; 2003.

40. Reid C. Wounds of Exclusion: Poverty, Women's Health and Social Justices. Edmonton: Qualitative Institute Press; 2004.

41. Dijkstra AG, van Donge JK. What does the 'show case' show? Evidence of and lessons from adjustment in Uganda. World Development 2001; 29(5): 841-863.

42. Koivusalo M, Mackintosh M: Health Systems and Commercialization: In Search of Good Sense. Geneva: United Nations Research Institute for Social Development; 2004.

43. Deininger K, Mpuga P. Economic and welfare effect of the abolition of health user fees: evidence from Uganda. Journal of African Economies 2004; 14(1): p. 55-91.

44. Uganda Bureau of Statistics Uganda Participatory Poverty Assessment Process: Ntungamo District Report. Kampala, Uganda Bureau of Statistics 2002. available at: [http://www.finance.go.ug/ $\begin{array}{lllll}\text { d } & 0 & \mathrm{c} & \mathrm{s}\end{array}$ Ntungamo $\% 20$ District $\% 20$ report $\% 20$ draft.pdf] 